\title{
Research on Influencing Factors of Consumer Shopping Behavior in Online Shopping Festival
}

\author{
Yang Liu ${ }^{a}$, Xuemeng Zhang, Yihe Zhang and Chunyan Qiu,** \\ School of Management Science and Information Engineering, Jilin University of Finance and Economics, \\ Changchun, 130117, China \\ a email: 7923759@qq.com, bemail: 81692002@qq.com \\ *Corresponding author
}

Keywords: Online shopping festival; Shopping behavior; Shopping motivation; Social influence; Congregation

\begin{abstract}
Studying the influencing factors of consumer shopping behavior during the online shopping festival is of great significance to the development of the shopping platform and the marketing strategy of the merchant. Based on shopping motivation theory, social influence theory and herd theory, this paper divides the influencing factors of consumer shopping behavior during online shopping festival into utilitarian shopping motivation, hedonic shopping motivation, social influence and herding four dimensions, and builds online shopping. A research model is built on the influencing factors of consumer shopping behavior during the festival. Data were collected through questionnaires, and statistical analysis and hypothesis testing were performed using SPSS and Smart PLS. The study found that utilitarian shopping motives, hedonic shopping motives, social influences and herdism significantly affected consumers' shopping behavior during the shopping festival, and social influences have a significant effect on the public.
\end{abstract}

\section{Introduction}

With the increasingly fierce competition in the online shopping market, various e-commerce shopping platforms have combined the special dates with large-scale online shopping promotion activities to promote sales, and constructed an online shopping festival. Since the first "Double Eleven" shopping festival in Taobao in 2009, the number of online shopping festivals has gradually increased, such as Taobao "Double Twelve” and Jingdong “618”. With the increase in the number of online shopping festivals and the increase in the frequency of hosting, the shopping behavior of consumers during the online shopping festival has gradually attracted the attention of scholars.

This paper takes the online shopping festival as the research situation and studies the influencing factors of consumer shopping behavior during the online shopping festival. It is believed that the shopping behavior of consumers during the online shopping festival is not only guided and dominated by shopping motives, but also influenced by social influence and herd. This paper constructs a research model of the influencing factors of consumer shopping behavior during the online shopping festival, and collects data through questionnaires. The empirical analysis verifies the motivation of shopping, social influence and the effect of herd on consumer shopping behavior. The research results are helpful to the shopping platform and Businesses in-depth analysis of consumer shopping behavior during the online shopping festival, market segmentation, improvement and development of marketing strategies, but also help consumers correctly understand the online shopping festival, increase rational consumption, is of great significance.

\section{Model Construction and Research Assumptions}

Based on shopping motivation theory, social influence theory and herd theory, this paper constructs a research model of factors affecting consumer shopping behavior during online shopping 
festival. As shown in Figure 1, the consumer shopping motivation is divided into utilitarian shopping motivation and hedonic type. Two dimensions of shopping motivation, by analyzing the guiding and dominance of shopping motives on consumer shopping behavior, as well as the role of social influence and audience-to-consumer shopping behavior, exploring shopping motives, social influences and herd-to-consumer shopping behavior during online shopping festivals The impact and extent of the effect.

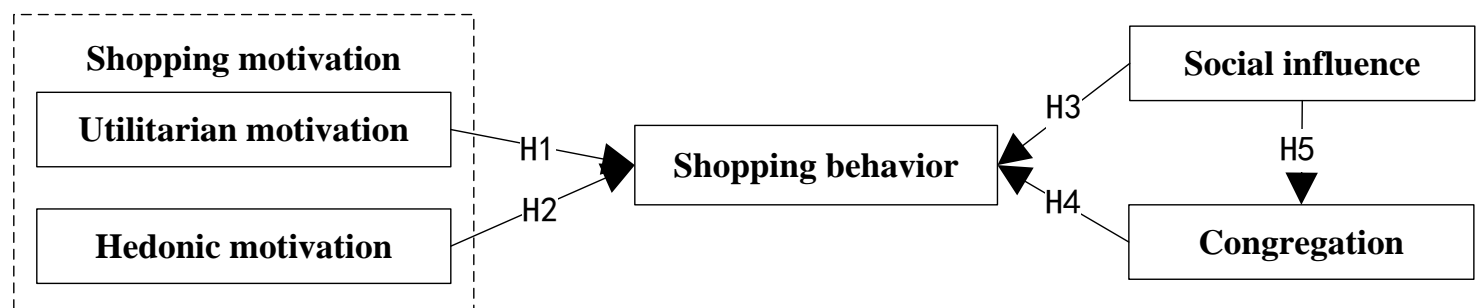

Figure 1: Research on The Influencing Factors of Consumer Shopping Behavior in Online Shopping Festival

Shopping motivation refers to the needs and desires of consumers in the shopping process, which is the direct cause and internal driving force that triggers the purchase behavior of consumers [1]. Tauber puts forward the theory of shopping motives for the problems caused by shopping activities. He believes that shopping is a series of behaviors of consumers acquiring goods and shopping value. It introduces consumers' demand for emotions in shopping process into shopping motivation theory [2]. Babin et al. classify shopping motives into utilitarian shopping motives and hedonic shopping motives [3]. One is based on the functional reasons of merchandise attributes, the other is based on the hedonistic reasons of emotional satisfaction attributes, and the shopping motive scale is developed [3]. Hirschman et al. believe that consumers of utilitarian shopping motives are looking for shopping with a mentality of completing tasks. It is a rational shopping, and its concern is whether it can efficiently and quickly purchase the goods and services it needs and complete the tasks to be purchased[5]; Consumers who enjoy the shopping motives are more concerned about and enjoy the shopping experience process, pursuing the value of hedonic shopping, and the shopping process is emotional, not simply to complete a shopping task[5].Childers introduce shopping motives into online shopping, and believe that online shopping motives are also divided into utilitarian and hedonic types[4]. Consumers of utilitarian shopping motives will pursue the utilitarian value of online shopping, such as the convenience of shopping, the saving of time cost, the availability and economy of the goods or services required, and the consumers of hedonic shopping motives. There is no clear shopping goal or task, and more is to enjoy the shopping process, so it is easy to be attracted by the visual and entertainment of the website, triggering the purchase behavior in the process of interacting with the platform. During the online shopping festival, consumers actively participate in online shopping festivals to purchase goods or services under the guidance and control of their utilitarian and hedonic shopping motives. Therefore, this paper proposes the following assumptions:

H1: Consumer utilitarian shopping motives during the online shopping festival significantly positively affected consumer buying behavior.

H2: Consumer hedonic shopping motives during the online shopping festival significantly positively affected consumer buying behavior.

Social Influence Theory (SIT) is a typical social psychology theory. It is widely used in user information system usage behaviors and consumer shopping behaviors to explain the formation of personal opinions and the change of behavioral attitudes. The theory of social influence believes that the change of individual behavior comes from the induction of external social influence factors, including the influence of others or groups [6]. Among them, others and groups mainly refer to leaders who are in the same social network as individuals and who are important to individuals, such as friends, partners, family members, etc., or who are sought after and respected by others, such as role models, idols, fashion leaders etc [7]. Xu et al. confirmed that the attitudes, willingness and 
behavior of consumers in the online shopping process will be significantly affected by those who are important to themselves, that is, the social impact theory is prominent in the online shopping process. During the online shopping festival, the behavior of consumers will be influenced by the shopping information, shopping intentions, and shopping behaviors of others or groups, and then the compliance, recognition or internalization of individual attitudes will be changed [7]. Therefore, this paper proposes the following assumptions:

H3: The social impact during the online shopping festival significantly positively affected the consumer's shopping behavior.

Conformity behavior is a universal phenomenon in social psychology. Its essence is the change of attitude or behavior of individuals under group pressure [8]. In consumer behavior, herd behavior is mainly manifested in a shopping behavior in which a consumer individual is influenced by the purchase intention or purchase behavior of another person or group, and changes his or her will or behavior [9]. Studies have confirmed that in shopping behavior, individual factors, group factors, situational factors and product factors will have an impact on the individual behavior of consumers [9]. In the online shopping environment, consumers face huge amounts of product information, and in the case of asymmetric information, they are easily affected by other consumer behaviors, such as product evaluation, number of purchases, number of collectors, and attention. At the same time, the online shopping platform is a kind of social business platform, and the purchasing behavior of others or groups in the social network can easily influence the individual group norms. Liu Jiang et al. verified through empirical analysis that online shopping users' attitudes, group norms and information asymmetry can significantly affect the herd behavior of online shopping consumers [11]. During the online shopping festival, merchants adopt various promotion methods and create a shopping festival atmosphere to attract consumers' attention. During the shopping festival, consumers are more susceptible to the purchase behavior of others or groups. Therefore, this paper proposes the following assumptions:

H4: During the online shopping festival, the audience significantly positively affected the consumer's shopping behavior.

Social influence and herd behavior are prominent in the online shopping process. Venkatesan believes that the influence or change of shopping attitudes and behaviors during consumer shopping is mainly from other people or groups in their social networks [10]. That is, when consumers cause herd behavior due to group norms and information asymmetry, the choice of herd behavior is more inclined to be influenced by the same social network in the environment and important individuals, such as friends, family, etc., or role models and idols. The influence of fashion leaders, etc [10], that is, herd behavior is more inclined to be subject to the mechanisms of compliance, identification and internalization in social influence. Therefore, this paper proposes the following assumptions:

H5: Social impacts have a significant positive impact on consumer compliance.

\section{Research Design and Empirical Analysis}

\subsection{Questionnaire design and variable measurement}

This paper mainly uses questionnaires to collect data. This part is the measure of shopping motivation, social influence, herd and shopping behavior. There are 5 latent variables. The measurement design of the latent variable mainly refers to the research results of the predecessors, and the shopping utilitarian shopping motive mainly refers to the research of Kevin [12]; Shopping festival hedonic shopping motivation mainly refers to Babin [3] research; social influence mainly refers to the study of Venkatesh [13]; public reference to Cheung [14] research; shopping behavior mainly refers to Dodds [15] and other research, and according to the online shopping festival scenario, appropriate adjustments and improvements. The questionnaire was measured using a Likert 5-level scale. The results of the pre-surveyed questionnaires were revised to form the final questionnaire. 


\subsection{Data collection and statistical analysis}

The questionnaire was mainly distributed and collected through the questionnaire software, and respondents were asked to fill out the questionnaire based on the latest shopping experience of participating in the online shopping festival. The questionnaire was distributed through online and offline methods. A total of 350 questionnaires were distributed and collected. After the invalid questionnaires were deleted, 298 remaining valid questionnaires, the effective rate was $85.14 \%$. The statistical analysis results of the data are shown in Table 1.

Table 1: Sample description statistics (298)

\begin{tabular}{|c|c|c|c|c|c|c|c|}
\hline Item & Range & Frequency & $\begin{array}{c}\text { Percentage } \\
(100 \%)\end{array}$ & Item & Range & Frequency & $\begin{array}{c}\text { Percentage } \\
(100 \%)\end{array}$ \\
\hline \multirow{2}{*}{ Gender } & Male & 138 & 46.31 & \multirow{5}{*}{$\begin{array}{c}\text { Personal } \\
\text { monthly } \\
\text { disposable } \\
\text { income }\end{array}$} & $\begin{array}{l}1,000 \text { yuan } \\
\text { and below }\end{array}$ & 10 & 3.36 \\
\hline & Female & 160 & 53.69 & & $\begin{array}{c}\text { 1001-3000 } \\
\text { yuan }\end{array}$ & 187 & 62.75 \\
\hline \multirow{6}{*}{ Age } & $\begin{array}{c}\text { Under } 18 \text { years } \\
\text { old }\end{array}$ & 13 & 4.36 & & $\begin{array}{c}\text { 3001-5000 } \\
\text { yuan }\end{array}$ & 73 & 24.50 \\
\hline & 18-24 years old & 138 & 46.31 & & $\begin{array}{c}\text { 5001-10000 } \\
\text { yuan }\end{array}$ & 25 & 8.39 \\
\hline & 25-35 years old & 102 & 34.23 & & $\begin{array}{c}10,000 \text { yuan } \\
\text { and above }\end{array}$ & 3 & 1.01 \\
\hline & 36-45 years old & 35 & 11.74 & \multirow{6}{*}{$\begin{array}{l}\text { Average } \\
\text { monthly } \\
\text { online } \\
\text { shopping } \\
\text { spend }\end{array}$} & $\begin{array}{l}500 \text { yuan } \\
\text { and below }\end{array}$ & 30 & 10.07 \\
\hline & $46-60$ years old & 10 & 3.36 & & $\begin{array}{l}\text { 501-1000 } \\
\text { yuan }\end{array}$ & 120 & 40.27 \\
\hline & $\begin{array}{c}60 \text { years old and } \\
\text { above }\end{array}$ & 0 & 0.00 & & $\begin{array}{c}1001-2000 \\
\text { yuan }\end{array}$ & 106 & 35.57 \\
\hline \multirow{4}{*}{$\begin{array}{l}\text { Education } \\
\text { level }\end{array}$} & $\begin{array}{l}\text { High school and } \\
\text { below }\end{array}$ & 10 & 3.36 & & $\begin{array}{c}2000-3000 \\
\text { yuan }\end{array}$ & 33 & 11.07 \\
\hline & Specialist & 13 & 4.36 & & $\begin{array}{l}3001-5000 \\
\text { yuan }\end{array}$ & 8 & 2.68 \\
\hline & Bachelor & 235 & 78.86 & & $\begin{array}{l}\text { More than } \\
5,000 \text { yuan }\end{array}$ & 1 & 0.34 \\
\hline & $\begin{array}{l}\text { Graduate and } \\
\text { above }\end{array}$ & 40 & 13.42 & \multirow{5}{*}{$\begin{array}{l}\text { Number of } \\
\text { online } \\
\text { shopping } \\
\text { sessions in } \\
\text { the last } \\
\text { three years }\end{array}$} & $1-5$ times & 41 & 13.76 \\
\hline \multirow{4}{*}{$\begin{array}{c}\text { Online } \\
\text { shopping } \\
\text { experience }\end{array}$} & Within 1 year & 8 & 2.68 & & $6-10$ & 114 & 38.26 \\
\hline & $1-3$ years & 75 & 25.17 & & 11-15 times & 78 & 26.17 \\
\hline & 3-5 years & 95 & 31.88 & & 15-20 times & 45 & 15.10 \\
\hline & $\begin{array}{c}\text { More than } 5 \\
\text { years }\end{array}$ & 120 & 40.27 & & $\begin{array}{c}\text { More than } \\
20 \text { times }\end{array}$ & 20 & 6.71 \\
\hline
\end{tabular}

\subsection{Reliability and validity test}

In this paper, data processing and statistical analysis using SPSS software, path analysis and hypothesis testing by Smart PLS software. Measuring the overall reliability of the questionnaire and the reliability of each latent variable by Cronbach's $\alpha$ value. The overall reliability of the questionnaire is Cronbach's $\alpha=0.906$, indicating that the overall reliability of the questionnaire is high. $\mathrm{KMO}=0.894$, indicating suitable for factor analysis. According to the reliability and validity test, the Cronbach's $\alpha$ values of each latent variable are greater than 0.7 , indicating that the reliability of each latent variable is higher. The combined reliability (CR) is greater than 0.7 , indicating that the internal consistency of each measurement item is better. Validity test mainly through two ways, polymerization validity and discriminant validity. The measured AVE is greater than 0.5 , indicating that the study has good polymerization validity. Discriminant validity is measured by comparing the square root of each factor AVE with the correlation coefficient between variables. The square root of the measured AVE value is greater than the correlation coefficient between variables, indicating that the sample has good discriminant validity. 


\subsection{Hypothesis Testing}

In this paper, the structural equation model is constructed by Smart PLS, and path analysis and hypothesis testing are performed. The PLS Algorithm (PLS algorithm) is used to verify the path relationship between variables and obtain R-square explanatory power. The R-square explanatory power mainly reflects the degree to which explanatory variables interpret the explanatory variables. The path analysis results and R-square values are shown in Figure 2. During the online shopping festival, utilitarian shopping motives, hedonic shopping motives, social influences and herd positively positively influenced consumers' shopping behaviors, explaining $49 \%$ of wake-up; social impacts significantly positively affect herd, and her interpretation to herd is $25.7 \%$ Through Boot Strapping, the level of significance between the variables, ie the T value, can be calculated. The level of significance is shown in Figure 2.

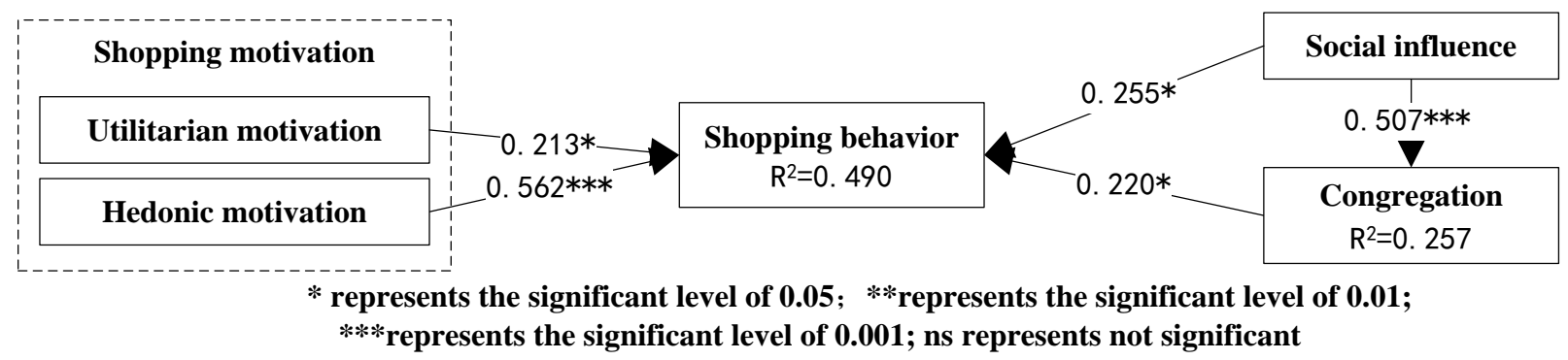

Figure 2: The path coefficient of research model and its significant level

\section{Research Results and Discussion}

In order to study the influencing factors of consumer shopping behavior during the online shopping festival, this paper builds a research model of the influencing factors of consumer shopping behavior during the online shopping festival based on shopping purchase theory, social influence theory and herd theory. The empirical analysis results are shown in Figure 2. All assumptions are supported. Utilitarian shopping motives, hedonic shopping motives, social influences, and herdism significantly influence consumer shopping behaviors, and social influences significantly influence herd.

1) Utilitarian shopping motives during online shopping festivals significantly affect consumer shopping behavior. The research results show that from the perspective of utilitarian shopping motivation, the main reason for consumers to participate in the shopping festival during the online shopping festival is the high efficiency of product selection during shopping festival, the cost of shopping, the information of products, and the convenience of shopping. As a festival for large-scale sales promotion, the online shopping festival attracts a large number of consumers to browse the goods and services they need during the shopping festival. Therefore, the shopping platform should capture the utilitarian shopping motive features of the consumer shopping festival. Economy, availability and information to attract consumers, the convenience and interactivity of the shopping platform to bring consumers the most convenient and fast, so that consumers can optimize the selection of goods and services during the online shopping festival, In this way, the competitive advantage of the shopping platform in many e-commerce companies is enhanced. At the same time, satisfying consumers' utilitarian shopping motives is conducive to improving consumer loyalty and renewed willingness, which is conducive to enterprises to promote product sales and build popularity, and lay a good foundation for the healthy development of enterprises.

2) The hedonic shopping motives during the online shopping festival significantly affect consumers' shopping behavior, and among the several influencing factors, the impact is the strongest. The research results show that during the online shopping festival, consumers are more likely to participate in the shopping festival than the utilitarian shopping motive. Shopping is not the goal of consumers simply participating in the shopping festival, but more to enjoy the shopping experience of 
the shopping festival. The pursuit of the realization of the enjoyable shopping value. Therefore, during the online shopping festival, the shopping platform should pay attention to the online shopping environment, actively create platform features, enhance the platform's visuality, and increase the consumer's enjoyment experience with beautiful web design and easy-to-use navigation system, with music background and video. Play to increase the effect of merchandising, shopping for entertainment games to assist merchandise sales, and increase the entertainment experience of consumers in the shopping process. Consumers of hedonic shopping motives often do not have specific shopping tasks, which generate purchase behavior through browsing and interaction with the platform through the hedonic experience. Satisfy consumers' hedonic shopping motives, making consumers' shopping behavior on the platform become a hedonic consumption, shopping in a full-fledged experience, maximizing consumer shopping satisfaction, and increasing consumer shopping festivals After the reconsideration of will.

3) Social influence during online shopping festivals significantly affects consumer shopping behavior. The research results show that during the online shopping festival, the people in the social network where the consumers are located are important to the consumers' shopping attitudes and behaviors, which will lead to changes in the shopping attitude of the consumers, and then promote or Impede the occurrence of consumer shopping behavior. Therefore, during the online shopping festival, the shopping platform should pay attention to the importance of the value of the consumer's word of mouth. The consumer's word-of-mouth recommendation behavior will strengthen the shopping attitude of others, and thus affect the subsequent purchase behavior. Fundamentally speaking, the shopping platform should first protect the quality and reputation of goods and services, and then adopt various methods to promote consumers' shopping sharing, store sharing, product recommendation, etc. At the same time, they can also adopt certain preferential strategies to promote consumer friends. Interactive activities such as coupon sharing and gifts are added to increase positive social impact and promote the healthy development of the shopping platform.

4) Conspicuous influence on consumer shopping behavior during the online shopping festival. The research results show that during the online shopping festival, consumers' purchasing attitudes and behaviors will be changed by the pressure of the consumer groups. During the online shopping festival of "Wandian Celebration" and "People's Purchase”, many shopping platforms and massive product information will cause consumers to have information asymmetry. Therefore, the popularity of the shop, the number of people in the store, and the number of people who purchase the goods. , word of mouth evaluation, etc. will have an impact on consumer purchasing decisions. Under the influence of information asymmetry and group norms, the choice of making a herd behavior is the least conflicting decision. Therefore, merchants should guarantee the quality of goods and services, promote sales with credit, and earn popularity with sales, which is the foothold in the online shopping market. From the perspective of consumers, when purchasing goods, you should purchase goods from actual demand, be wary of bad merchants to maliciously print orders to promote sales, or temptation buyers to falsely praise.

5) Social influence significantly affects consumer secularity and explains the herd to $50.7 \%$. The research results show that during the online shopping festival, when consumers are caused by information asymmetry or group norms, their choices are more inclined to be subject to the same social network in their environment and to important individuals such as friends and family members. Or the influence of role models, idols, etc. It can be seen that the role of social influence in consumer behavior is not negligible. During the online shopping festival, when developing marketing strategies, the shopping platform should pay attention to the influence of social networks and reference groups on consumer shopping behavior and herd behavior, and rationally set marketing strategies.

\section{Research conclusion and prospect}

Based on shopping motivation theory, social influence theory and herd theory, this paper divides shopping motives during online shopping festival into utilitarian shopping motives and hedonic shopping motives, and analyzes shopping motives to consumers' shopping behaviors. Guide and 
dominance, as well as the influence of social influence and herd on consumer shopping behavior, constructed a research model of factors influencing consumer shopping behavior during online shopping festival. Data were collected through questionnaires for statistical analysis and hypothesis testing. The study found that utilitarian shopping motives, hedonic shopping motives, social influences, and herdism significantly influenced shopping behavior during the festival, and social influence significantly affected herd.

Although the research hypotheses have been verified, there are still some limitations in the research: (1) This paper mainly selects the two most significant shopping motives during the shopping festival. In future research, you can try to different shopping motives. Angle classification, conducting empirical research. (2) The factors affecting consumers' shopping behavior during the online shopping festival are multi-faceted. In recent years, the influence of online shopping festivals is increasing. The shopping environment and shopping atmosphere during shopping festivals also have an impact on consumer behavior. Therefore, in future research, we can try to study the consumer shopping behavior of online shopping festival from many aspects.

\section{Acknowledgments}

This paper is supported by the Changchun City Philosophical and Social Science Planning Project "Research on the Measurement of Public Happiness and Its Influencing Factors in Changchun City”(No. CSKT2018ZX-010) And Jilin University of Finance and Economics Doctoral Fund

Project "Research on User Privacy Information Disclosure Behavior and Protection Mechanism in Online Medical Health Service”(No. 2018B15).

\section{References}

[1] Xin Xin, Liu Wenchao, Ren Junsheng. A Review of Consumers' Shopping Motivation Research[J]. Taxation and Economy,2018(01):62-67.

[2] Tauber EM. Why Do People Shop? [J]. Journal of Marketing, 1972, 36 (4):46-49.

[3] Babin BJ, Darden WR, Griffin M. Work and/or Fun: Measuring Hedonic and Utilitarian Shopping Value [J]. Journal of Consumer Research, 1994, 20 (4) :644-656

[4] Childers TL, Carr CL, Peck J, et al. Hedonic and Utilitarian Motivations for Online Retail Shopping Behavior[J]. Journal of Retailing, 2001, 77(4):511-535.

[5] Hirschman EC, Holbrook MB. Hedonic Consumption: Emerging Concepts, Methods and Propositions[J]. Journal of Marketing, 1982 , 46 (3) :92-101.

[6] Kelman H C. Further Thoughts on the Processes of Compliance, Identification, and Internalization, In Social Influence and Linkages between the Individual and the Social System [M]. Chicago: Aldine Press, 1974: 125-71.

[7] ZHANG Zheng-lin, ZHUANG Gui-jun. Research on Impulse Purchase Based on Social Influence and Face Perspective[J]. Management Science,2008,21(06):66-72.

[8] Myers DG. Exploring social psychology [M]. 5th ed. New York: McGraw-Hill, 2009.

[9] Lascu DN, Zinkhan G. Consumer Conformity: Review and Applications for Marketing Theory and Practice[J]. Journal of Marketing Theory and Practice, 1999, 7 (3) :1-12.

[10] Venkatesan M. Experimental Study of Consumer Behavior Conformity and Independence [J]. Journal of Marketing Research, 1966, 3 (4) :384-387.

[11]Liu Jiang, Zhu Qinghua, Wu Kewen, Zhao Yuxiang. An Empirical Study on the Influencing Factors of Essay Behavior of Online Shopping Users[J]. Library and Information Service, 2012, 56 (12):138-143+147. 
[12]Kevin E voss, Eric R Spangenberg, Bianca Grohmann. Messuring the hedonic and utilitarian dimensions of consumer attitude [J]. Journal of Marketing Research. 2003, 40(3):310-320.

[13] Venkatesh V, Morris M G, Davis G B, et al. User acceptance of information technology: toward a unified view[J]. Mis Quarterly, 2003, 27(3):425-478.

[14] Cheung C M K, Chiu P Y, Lee M K O. Online Social NetWorks: Why do Students Use Facebook? [J]. Computers in Human Behavior, 2010, 7(28):1-6.

[15]Dodds WB, Monroe KB, Grewal D. Effect of Price, Brand, and Store Information on Buyers' Product Evaluations[J]. Journal of Marketing Research,1991, 28(3): 307-319. 